\title{
Hierarchy Analysis Method as Investment Decision Support Tool
}

\author{
Kotelnikov Nikolai Vladimirovich \\ Industrial Management Department, \\ Economics, Management and Law Institute, \\ Irkutsk National Research Technical University \\ Irkutsk, Russian Federation \\ nik_kot77@mail.ru
}

\author{
Urazova Nina Gennadievna \\ Industrial Management Department, \\ Economics, Management and Law Institute, \\ Irkutsk National Research Technical University \\ Irkutsk, Russian Federation \\ urazova_nina@mail.ru
}

\author{
Ohanova Alexandra Mikhailovna \\ Industrial Management Department, \\ Economics, Management and Law Institute, \\ Irkutsk National Research Technical University \\ Irkutsk, Russian Federation \\ 6trrytr@mail.ru
}

\begin{abstract}
The research deals with the issues of upgrading manufacturing sector, changes of industrial management forms and methods, fixed asset renewal, and implementation of advanced management systems. The article describes ranking processes and methods for choosing investment modernization projects for chemical plants. The method is used to choose an investment project based on quantitative and qualitative criteria. The article presents calculations used to choose a priority project for upgrading the chemical industry.
\end{abstract}

Key words - upgrading, project, decision choice, analytical hierarchy method.

\section{INTRODUCTION}

At present, the Russian manufacturing sector needs upgrading, changing industrial management forms and methods, reequipping and implementing more advanced management systems.

Large-scale reequipment of the manufacturing sector was carried out during the industrialization and in the postwar period. Since then new equipment has been installed only in new and defense plants, while other plants have never been reconstructed. In order to be competitive and labor efficient, many Russian manufacturing sectors require upgrading.

The chemical industry is a heavy industry which involves chemical processing of various raw materials. The Russian chemical industry is one of the basic industries. According to the amount of fixed assets, it comes fourth after the fuel and energy industry, machine building industry and metallurgical industry. The significance of the chemical industry for the Russian economy is due to its crucial role as a key industry.

Chemical plants manufacture more than 70000 different products. They supply raw materials, half-finished products, different materials and goods (plastics, chemical fibers, tires, paints and vanishes, mineral fertilizers, feed supplements, medicines, medical equipment, etc.) for all other industries. The main consumers of those products are agricultural, metallurgical, machine building, and textile industries. Chemical plants themselves consume more than $25 \%$ of their own products.

The chemical industry influences the efficiency of new promising areas in the above-mentioned industries. Chemical plants are one of the main centers for new knowledge, innovation and high technology. That means that they have high research intensity (more than $3.5 \%$ ). Russian chemical plants employ about 385000 workers [1].

Share of the chemical production in the structure of the Russian GDP is rather low. It is about $1-2 \%$. As a result of the economic situation in 2014-2016, chemical production increased by $6.3 \%$ demonstrating the best result among the key manufacturing sectors. Devaluation and import substitution program development had a positive impact on the growth of chemical production. It should be noted that Russia ranks $11^{\text {th }}$ in the world for chemical production. Its share of chemical products is $2 \%$.

Russia is lagging behind the leaders - the USA and China - due to negative effects of the following factors:

1. Heavy wear of manufacturing facilities. High workload of chemical plants (80-90\%) results in rapid wear. Gross book value of fixed assets of the chemical industry is 826.9 trillion rubles. According to statistics [2], the share of machines and equipment in the structure of fixed assets is $53.4 \%$. Russian equipment installed in some plants has worse characteristics compared to the foreign one. Equipment lifetime in Russia is $20-25$ years. In the USA, for example, it is about six years. Wear degree for fixed assets in Russian chemical plants is $42.2 \%$, share of used-up equipment is $14.1 \%$. In 2016, fixed asset investment was more than 360 billion rubles. Fixed asset renewal coefficient was 5.4\% [2]. Fixed asset aging causes fast production cost growth rate for the main types of industrial products, makes 
the chemical industry unattractive for national and foreign investors, destroys inter-industry relations, and strengthens negative environmental impacts of chemical plants [1]. Fixed asset renewal is a crucial task for chemical plants. It should be a part of the innovative activities and manufacturing of high quality competitive products. Owing to worn-out equipment, the chemical industry is lowefficient.

2. Lack of raw materials and high prices. The problem was identified by comparing raw material prices on the domestic and world markets. Besides, the Russian strategic chemical industries use imported raw materials.

3. Foreign economic policy failure. At present, it is evident that in the structure of the exported chemical products, share of low and middle-added value products is larger than in the structure of imported ones.

4. Poor state of human resources, scientific and technological potential, including: low $R \& D$ cost which is much lower than in many developed countries; shortage of qualified workers - the number of new chemical experts is rapidly decreasing due to brain drain and chemical staff training and retraining system destruction.

5. Inefficient public regulation, quality and standards system control. Import duties prevent development of the chemical manufacturers producing high-added value products. Access to modern foreign technologies is limited. Producers are not encouraged to develop more energyefficient technologies and increase raw materials processing depth. Industry standards are either not timely upgraded or lacking.

6. Domestic market undercapacity. Weak demand for chemical products on the domestic market decreases the chemical output.

7. Inefficient investment process and heavy taxes. Under the current financial conditions, chemical manufacturers have zero returns or losses. Most Russian chemical producers use their profits for current asset purchase and equipment repair.

8. Lack of competitive chemical equipment, low production automation. Equipment installed in Russian plants fails to meet modern quality requirements. There are no safety certificates and maintenance systems. Foreign equipment is expensive and not affordable.

9. Innovative inactivity of Russian chemical manufacturers. Share of innovatively active chemical producers in Russia is $25-26 \%$ while in developed countries that share is $33-65 \%$.

Thus, it is necessary to solve the above-mentioned problems in the chemical industry which is an important sector of the Russian industry influencing the Russian economics since it has a macroeconomic effect and influences the level of the national competitiveness and economy's growth rate.
Analysis of development trends in the chemical industry showed that it needs upgrading equipment. Upgrading in its turn requires financial support. Choosing a form of financial support for reequipment is as crucial as re-equipping itself. These measures expand technological and industrial potential of the producer, raise competitive capacity of chemical products, encourage innovative activities which will positively influences the chemical plants and national economy.

Thus, among the systemic problems of the domestic industry preventing its development, one could mention physical and moral deterioration of fixed assets due to weak innovative activities of producers, and mismatch between the technical state of plants and need for producing competitive products. Worn-out equipment modernization could solve those problems.

V.K. Faltsman, a Russian economist, defines [3] the technical reequipment as innovative equipment development, renewal of products, fixed assets and facilities, implementation of resource saving technology which gains advantages over competitors for a producer, industry or the whole economy. Increasing demand for equipment modernization causes need for choosing forms and sources of financial support. It becomes obvious that the crucial task of producers modernizing equipment is efficient financial support for worn-out equipment modernization, replacement of manufacturing lines, preproduction engineering for new products. Choosing and ranking investment modernization projects is a topical issue.

The choice of a project should be efficient because of limited financial resources of plants. There is a number of methods applied for choosing a dominant investment project or forming a portfolio of projects.

\section{METHODS}

To identify the best project for chemical industry modernization, we suggest using a hierarchy analysis method (HAM) developed by an American mathematician Thomas L. Saaty [4] in the beginning of the 1970s. The author referred to it as 'Analytic hierarchy process' (AHP) a decision support procedure.

Analytic hierarchy process is a technique for choosing the best alternative based on pairwise comparison of alternatives expressed in the form of priority eigenvectors by all criteria in the hierarchy. The HAM is used to evaluate all alternatives and choose the best one for reaching the goal [5]. A project with a larger value of priorities is dominant. If several projects have similar values, additional comparisons are required for choosing a dominant project. The method is used to analyze problems, discuss them, evaluate and minimize the inconsistency of data, evaluate each factor and decision stability. When choosing projects, the HAM helps easily determine the value of different factors influencing project efficiency. However, the method has some drawbacks: labor intensity, need for reviewing data in order to minimize inconsistencies, subjectivity. 
The procedure can be summarized as:

1. Structuring a decision problem as a hierarchical structure with several levels: goals - criteria - alternatives (Figure 1).

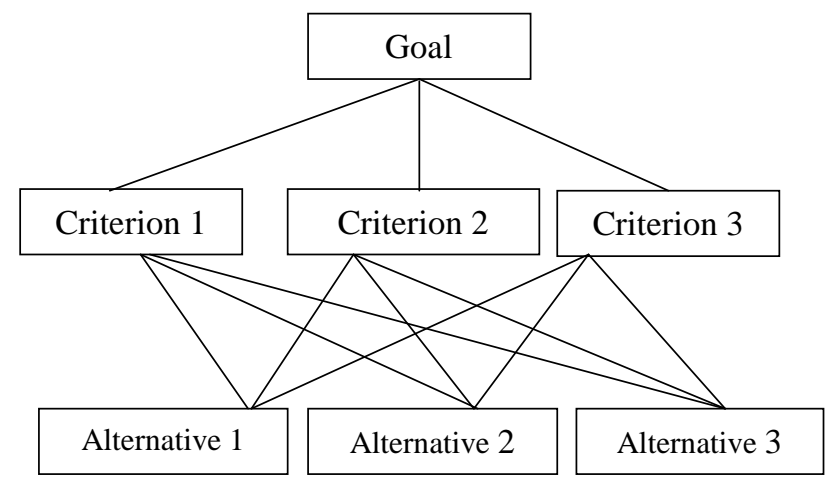

Fig. 1. Alternative hierarchy method

The number of hierarchical levels and criteria is unlimited. For decision accuracy, the manager determines alternatives and criteria.

2. Pairwise comparison of the elements of each level by a decision maker. Comparison results have numerical values.

3. Calculation of the priority values for the elements of each level; checking the consistency of the judgments. Criteria $\mathrm{C}_{\mathrm{i}}$ and alternatives $\mathrm{A}_{\mathrm{k}}(\mathrm{k}=1 \ldots \mathrm{m})$ are pairwise compared against different criteria for preference. The results are summarized in a table (Tables 1 and 2).

TABLE I. PAIRWISE COMPARISON OF CRITERIA

\begin{tabular}{|l|l|l|l|l|l|c|}
\hline \multirow{2}{*}{ Criterion } & \multicolumn{4}{|c|}{ Criterion } & Eigenvector & $\begin{array}{c}\text { Wei } \\
\text { ght }\end{array}$ \\
\cline { 2 - 5 } & $\mathrm{C}_{1}$ & $\mathrm{C}_{2}$ & $\ldots$ & $\mathrm{C}_{\mathrm{n}}$ & & \\
\hline $\mathrm{C}_{1}$ & $\mathrm{C}_{11}$ & $\mathrm{C}_{12}$ & $\ldots$. & $\mathrm{C}_{1 \mathrm{n}}$ & $\delta_{1}$ & $\mathrm{~W}_{1}$ \\
\hline $\mathrm{C}_{2}$ & $\mathrm{C}_{21}$ & $\mathrm{C}_{22}$ & $\ldots$. & $\mathrm{C}_{2 \mathrm{n}}$ & $\delta_{2}$ & $\mathrm{~W}_{2}$ \\
\hline$\ldots$ & $\ldots$ & $\ldots$ & $\ldots$ & $\ldots$ & $\ldots$ & $\ldots$ \\
\hline $\mathrm{C}_{\mathrm{n}}$ & $\mathrm{C}_{\mathrm{n} 1}$ & $\mathrm{C}_{\mathrm{n} 2}$ & $\ldots$ & $\mathrm{C}_{\mathrm{nn}}$ & $\delta_{\mathrm{n}}$ & $\mathrm{W}_{\mathrm{n}}$ \\
\hline
\end{tabular}

TABLE II. PAIRWISE COMPARISON OF ALTERNATIVES

\begin{tabular}{|l|l|l|l|l|r|r|}
\hline \multirow{2}{*}{ Alternative } & \multicolumn{5}{|c|}{ Alternative } & Eigen- \\
& $\mathrm{A}_{1}$ & $\mathrm{~A}_{2}$ & $\ldots$ & $\mathrm{A}_{\mathrm{m}}$ & Wector & \\
\hline $\mathrm{A}_{1}$ & $\mathrm{~A}_{11}$ & $\mathrm{~A}_{12}$ & $\ldots$ & $\mathrm{A}_{1 \mathrm{~m}}$ & $\gamma_{1}$ & $\mathrm{v}_{1}$ \\
\hline $\mathrm{A}_{2}$ & $\mathrm{~A}_{21}$ & $\mathrm{~A}_{22}$ & $\ldots$ & $\mathrm{A}_{2 \mathrm{~m}}$ & $\gamma_{2}$ & $\mathrm{v}_{2}$ \\
\hline$\ldots$ & $\ldots$ & $\ldots$ & $\ldots$ & $\ldots$ & $\ldots$ & $\ldots$ \\
\hline $\mathrm{A}_{\mathrm{m}}$ & $\mathrm{A}_{\mathrm{m} 1}$ & $\mathrm{~A}_{\mathrm{m} 2}$ & $\ldots$ & $\mathrm{A}_{\mathrm{mm}}$ & $\gamma_{\mathrm{n}}$ & $\mathrm{v}_{\mathrm{m}}$ \\
\hline
\end{tabular}

The table cells are filled in as follows:

$$
C_{i j}=1, \quad i, j=1 \ldots n ; \quad A_{k l}=1, \quad k, l=1 \ldots m
$$

If $\mathrm{C}_{\mathrm{i}}$ is more desirable than $\mathrm{C}_{\mathrm{j}}$, then $C_{i j}=\{1,3,5,7,9\}$. The same is true for the alternatives: if $\mathrm{A}_{\mathrm{i}}$ is more desirable than $\mathrm{A}_{\mathrm{j}}$, then $A_{i j}=\{1,3,5,7,9\}$. Here 1 is equality, 3 - slight priority, 5 - significant priority, 7 - high priority, 9 - crucial priority.

For less desirable alternatives, reverse values are written by formula:
$\mathrm{C}_{i j}=\frac{1}{\mathrm{C}_{i j}}, A_{k l}=\frac{1}{A_{k l}}$

4. Values of the eigenvectors are calculated by formulas 2 and 3:

$$
\begin{gathered}
\delta_{i}=\sqrt[n]{c_{i 1} * c_{i 2} * \ldots * c_{i n}}, \\
\gamma_{i}=\sqrt[m]{A_{k 1} * A_{k 2} * \ldots * A_{k m}},
\end{gathered}
$$

5. Using formulas 4 and 5 , the weight - a standardized value of eigenvectors $\delta_{\mathrm{i}}$ and $\gamma_{\mathrm{k}}$ - is calculated:

$W_{i j}=\frac{\delta_{i}}{\sum_{i=1}^{n} \delta_{i}}, \sum_{i=1}^{n} w_{i}=1$
$v_{k}=\frac{\gamma_{k}}{\sum_{k=1}^{m} \gamma_{k}}, \sum_{k=1}^{m} v_{k}=1$

6 . The summary table of weights of the criteria is created. The integrated index for each alternative is calculated by formula 6 :

$E_{i}=\sum_{i=1}^{n} w_{i} v_{i j}, j=1 \ldots m$

7. The alternative with the largest integrated index $E=\max _{i}$ $\mathrm{E}_{\mathrm{i}}$ is considered optimal.

\section{RESULTS}

To show the application of the HAM, we used JSC Angarsk Polymer Plant as an example. The modernization program consists of six projects designated as:

- EP - $300\left(\mathrm{~A}_{1}\right)$ reconstruction;

- Polyethylene production unit $\left(\mathrm{A}_{2}\right)$;

- Polypropylene production unit $\left(\mathrm{A}_{3}\right)$;

- Off-sites of EP, PE, PP $\left(\mathrm{A}_{4}\right)$;

- Warehouse reconstruction $\left(\mathrm{A}_{5}\right)$;

- Reservoir park extension $\left(\mathrm{A}_{6}\right)$.

Implementation of each project boosts efficiency, reliability of equipment utilization, reduces operating costs, increases profits. However managers should establish priorities among the projects and choose the best ones for reaching the goal.

Identification of possible criteria for evaluating investment projects and development of a hierarchical structure are the first steps of the procedure. Taking into account the specific character of chemical industry modernization, we suggested the following criteria for evaluating the projects:

- $\mathrm{C}_{1}$ - net present value (NPV);

- $\mathrm{C}_{2}$ - amount of investment;

$-\mathrm{C}_{3}$ - project innovation degree;

- $\mathrm{C}_{4}$ - project elaboration degree;

$-\mathrm{C}_{5}$ - returns of the scale.

Innovation degree, elaboration degree and returns of the scale are determined in points (from 1 to 5). The more elaborated, efficient and innovative the project is, the higher its point is. Implementation of that project causes significant systemic changes. All the criteria, except for the amount of investment and NPV, are qualitative and integrated.

After qualitative and quantitative criteria have been identified, a hierarchical structure can be created (Figure 2) 


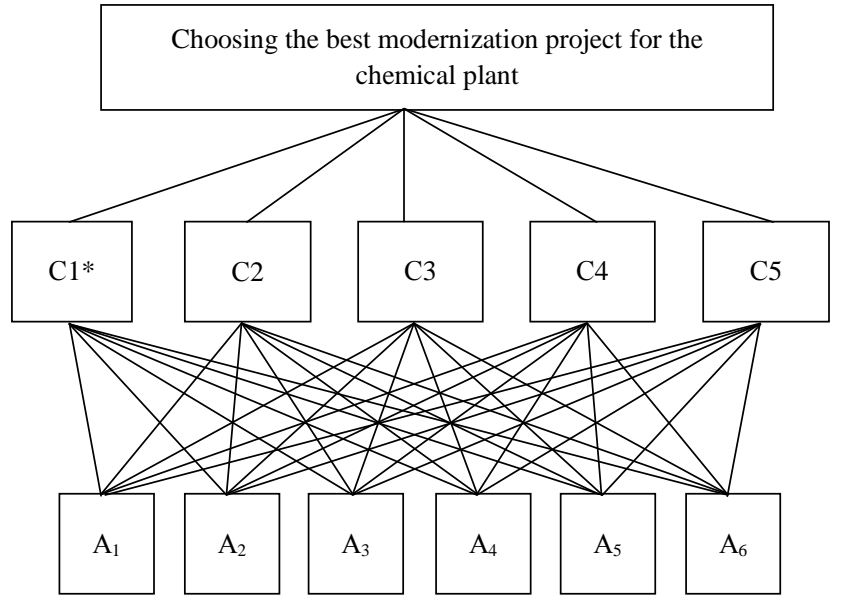

*- criterion

Fig. 2. An Analysis Hierarchy Structure used in choosing a dominant modernization project for JSC APP.

Then we create a pairwise comparison matrix and determine priorities of the criteria (Table 3).

TABLE III. PAIRWISE CRITERIA COMPARISON MATRIX

\begin{tabular}{|l|l|l|l|l|l|l|l|}
\hline & $\mathrm{C}_{1}$ & $\mathrm{C}_{2}$ & $\mathrm{C}_{3}$ & $\mathrm{C}_{4}$ & $\mathrm{C}_{5}$ & $\delta$ & $\mathrm{v}$ \\
\hline $\mathbf{C}_{\mathbf{1}}$ & $\mathbf{1 . 0 0}$ & $\mathbf{3 . 0 0}$ & $\mathbf{5 . 0 0}$ & $\mathbf{3 . 0 0}$ & $\mathbf{5 . 0 0}$ & $\mathbf{4 5 . 0 0}$ & $\mathbf{0 . 9 2}$ \\
\hline $\mathrm{C}_{2}$ & 0.33 & 1.00 & 5.00 & 2.00 & 5.00 & 3.33 & 0.07 \\
\hline $\mathrm{C}_{3}$ & 0.20 & 0.20 & 1.00 & 0.20 & 3.00 & 0.005 & 0.0001 \\
\hline $\mathrm{C}_{4}$ & 0.33 & 0.50 & 5.00 & 1.00 & 5.00 & 0.83 & 0.02 \\
\hline $\mathrm{C}_{5}$ & 0.20 & 0.20 & 0.33 & 0.20 & 1.00 & 0.001 & 0.00001 \\
\hline \multicolumn{7}{|l|}{ Total } \\
\hline
\end{tabular}

Table 3 shows that $\mathrm{C}_{1}$, has the largest value. Its eigenvector is 45,00 , and its weight is 0,92 .

As far as the NPV and amount of investment are objective criteria, their values are standardized so that their sum is equal to 1. Calculation results are presented in Tables 4 and 5.

TABLE IV. STANDARDIZED NPV VALUES

\begin{tabular}{|l|c|c|}
\hline \multicolumn{1}{|c|}{ Alternative } & NPV (mln. rubles) & $\begin{array}{c}\text { Standardized } \\
\text { value }\end{array}$ \\
\hline $\mathrm{A}_{1}$ & 345.0 & 0.245 \\
\hline $\mathrm{A}_{2}$ & 434.1 & 0.308 \\
\hline $\mathrm{A}_{3}$ & 316.3 & 0.224 \\
\hline $\mathrm{A}_{4}$ & 263.0 & 0.186 \\
\hline $\mathrm{A}_{5}$ & 6.0 & 0.004 \\
\hline $\mathrm{A}_{6}$ & 46.6 & 0.033 \\
\hline Total & 1411 & 1.00 \\
\hline
\end{tabular}

Table 5 - Standardized values of the amount of financial support

\begin{tabular}{|l|c|c|}
\hline Alternative & $\begin{array}{c}\text { Amount of financial } \\
\text { support (mln. } \\
\text { rubles) }\end{array}$ & $\begin{array}{c}\text { Standardized } \\
\text { value }\end{array}$ \\
\hline $\mathrm{A}_{1}$ & 11296 & 0.245 \\
\hline $\mathrm{A}_{2}$ & 14212 & 0.308 \\
\hline $\mathrm{A}_{3}$ & 10356 & 0.224 \\
\hline $\mathrm{A}_{4}$ & 8609 & 0.186 \\
\hline $\mathrm{A}_{5}$ & 197 & 0.004 \\
\hline $\mathrm{A}_{6}$ & 1525 & 0.033 \\
\hline Total & 46195 & 1.00 \\
\hline
\end{tabular}

Tables 4 and 5 show that $\mathrm{A}_{2}$ has larger values of the NPV and amount of financial support.

Then we develop matrices of pairwise comparison of the projects against $\mathrm{C}_{3}, \mathrm{C}_{4}$, and $\mathrm{C}_{5}$ and calculate eigenvectors and weights of the projects by the above-cited formula. The results are presented in Tables 6,7 and 8 .

TABLE V. PAIRWISE COMPARISON OF THE PROJECTS AGAINST C3

\begin{tabular}{|c|c|c|c|c|c|c|c|c|}
\hline & $\mathrm{A}_{1}$ & $\mathrm{~A}_{2}$ & $\mathrm{~A}_{3}$ & $\mathrm{~A}_{4}$ & $\mathrm{~A}_{5}$ & $\mathrm{~A}_{6}$ & $\gamma$ & $\mathrm{V}$ \\
\hline $\mathrm{A}_{1}$ & 1.00 & 0.20 & 0.20 & 5.00 & 5.00 & 5.00 & 0.833 & 0,004 \\
\hline $\mathrm{A}_{2}$ & 3.00 & 1.00 & 3.00 & 5.00 & 5.00 & 5.00 & 187.5 & 0.896 \\
\hline $\mathrm{A}_{3}$ & 3.00 & 0.33 & 1.00 & 5.00 & 5.00 & 5.00 & 20.833 & 0.0996 \\
\hline $\mathrm{A}_{4}$ & 0.20 & 0.20 & 0.20 & 1.00 & 0.33 & 0.33 & 0.0001 & 0.000001 \\
\hline $\mathrm{A}_{5}$ & 0.20 & 0.20 & 0.20 & 3.00 & 1.00 & 0.33 & 0.001 & 0.000006 \\
\hline $\mathrm{A}_{6}$ & 0.20 & 0.20 & 0.20 & 3.00 & 3.00 & 1.00 & 0.012 & 0.00006 \\
\hline
\end{tabular}

TABLE VI. PAIRWISE COMPARISON OF THE PROJECTS AGAINST C4

\begin{tabular}{|c|c|c|c|c|c|c|c|c|}
\hline & $\mathrm{A}_{1}$ & $\mathrm{~A}_{2}$ & $\mathrm{~A}_{3}$ & $\mathrm{~A}_{4}$ & $\mathrm{~A}_{5}$ & $\mathrm{~A}_{6}$ & $\gamma$ & $\mathrm{V}$ \\
\hline $\mathrm{A}_{1}$ & 1.00 & 0.33 & 0.33 & 5.00 & 5.00 & 5.00 & 2.31 & 0.01 \\
\hline $\mathrm{A}_{2}$ & 3.00 & 1.00 & 2.00 & 5.00 & 5.00 & 5.00 & 125.00 & 0.79 \\
\hline $\mathrm{A}_{3}$ & 3.00 & 0.50 & 1.00 & 5.00 & 5.00 & 5.00 & 31.25 & 0.20 \\
\hline $\mathrm{A}_{4}$ & 0.20 & 0.20 & 0.20 & 1.00 & 0.33 & 0.33 & 0.0001 & 0.000001 \\
\hline $\mathrm{A}_{5}$ & 0.20 & 0.20 & 0.20 & 3.00 & 1.00 & 0.50 & 0.0020 & 0.000013 \\
\hline $\mathrm{A}_{6}$ & 0.20 & 0.20 & 0.20 & 3.00 & 2.00 & 1.00 & 0.008 & 0.00005 \\
\hline \multicolumn{9}{|l|}{ Total } \\
\end{tabular}

TABLE VII. PAIRWISE COMPARISON OF PROJECTS AGAINST C5

\begin{tabular}{|l|l|l|l|l|l|l|l|l|}
\hline & $\mathrm{A}_{1}$ & $\mathrm{~A}_{2}$ & $\mathrm{~A}_{3}$ & $\mathrm{~A}_{4}$ & $\mathrm{~A}_{5}$ & $\mathrm{~A}_{6}$ & $\gamma$ & $\mathrm{v}$ \\
\hline $\mathrm{A}_{1}$ & 1.00 & 0.20 & 0.25 & 5.00 & 3.00 & 2.00 & 0.25 & 0.0007 \\
\hline $\mathrm{A}_{2}$ & 5.00 & 1.00 & 2.00 & 7.00 & 5.00 & 5.00 & 291.67 & 0.8327 \\
\hline $\mathrm{A}_{3}$ & 4.00 & 0.50 & 1.00 & 7.00 & 5.00 & 5.00 & 58.33 & 0.1665 \\
\hline $\mathrm{A}_{4}$ & 0.20 & 0.14 & 0.14 & 1.00 & 0.33 & 0.33 & 0.0001 & 0.0000002 \\
\hline $\mathrm{A}_{5}$ & 0.33 & 0.20 & 0.20 & 3.00 & 1.00 & 0.50 & 0.0033 & 0.0000095 \\
\hline $\mathrm{A}_{6}$ & 0.50 & 0.20 & 0.20 & 3.00 & 2.00 & 1.00 & 0.02 & 0.0001 \\
\hline \multicolumn{10}{|l|}{ Total } \\
\hline
\end{tabular}

Pairwise comparison of the projects is followed by creating a summary matrix using the values of weights in Tables 4, 5, 
6, 7 and 8. Index $\mathrm{E}$ is calculated by formula 6 for each project.

The weights should be ranked (I, II, III, etc). Implementation order for modernization projects at JSC APP should be based on those weights (far right column in Table 9).

TABLE VIII. SUMMARY MATRIX OF THE PRIORITIES OF MODERNIZATION PROJECTS COMPARED AGAINST A SET OF CRITERIA

\begin{tabular}{|c|c|c|c|c|c|c|c|}
\hline & $\mathrm{V}_{1}$ & $\mathrm{~V}_{2}$ & $\mathrm{~V}_{3}$ & $\mathrm{~V}_{4}$ & $\mathrm{~V}_{5}$ & $\mathrm{E}$ & Range \\
\hline $\mathrm{A}_{1}$ & 0.245 & 0.245 & 0.004 & 0.01 & 0.0007 & 0.241 & II \\
\hline $\mathrm{A}_{2}$ & 0.308 & 0.308 & 0.896 & 0.79 & 0.8327 & 0.316 & $\mathrm{I}$ \\
\hline $\mathrm{A}_{3}$ & 0.224 & 0.224 & 0.0996 & 0.2 & 0.1665 & 0.224 & $\mathrm{III}$ \\
\hline & 0.186 & 0.186 & 0.000001 & 0.000001 & 0.0000002 & 0.183 & IV \\
\hline $\mathrm{A}_{5}$ & 0.004 & 0.004 & 0.000006 & 0.000013 & 0.000009 & 0.004 & $\mathrm{VI}$ \\
\hline $\mathrm{A}_{6}$ & 0.033 & 0.033 & 0.00006 & 0.00005 & 0.0001 & 0.032 & $\mathrm{~V}$ \\
\hline
\end{tabular}

Table 9 shows that the key modernization projects are as follows: 'Polyethylene production unit' which has a priority against all criteria. It has rank I; 'EP-300 reconstruction' project and 'Polypropylene production unit' project with ranks II and III lag behind.

\section{CONCLUSION}

To sum up, the method for choosing priority investment projects suggested in the article is advisory. It is one of the investment decision support tools which has the following advantages:

- choosing a project based on a set of qualitative and quantitative criteria;

- detailed understanding of how these criteria influence each project;

- identification of the criterion which has to be to influenced in order to contribute to efficient project development.

The hierarchy analysis method allows decision makers to choose an alternative which would be in line with their grasp of the problem area and problem solving requirements.

\section{Acknowledgment}

We are responsible for all errors as well as heavy style of the manuscript.

\section{References}

[1] A.V. Volkova, Market of bulk polymers. Part 1. Moscow: National Research University Higher School of Economics, 2016.

[2] Federal State Statistics Service (Rosstat). Russia in numbers. Moscow, 2016.

[3] V.K. Faltsman, "Import substitution in Russian industries," Predicting issues, Vol. 5, pp. 52-62, 2015.

[4] T. Saaty, K. Kerns, Analitical planning. The organization of systems, Moscow: Radio and Communication, 1991.

[5] T. Saaty, Decision making. Hierarchy analysis method, Moscow, 1993. 